\title{
Morphology of Parastrongylidium estevesi comb. nov. and Deviata brasiliensis sp. nov. (Ciliophora: Stichotrichia) from a sewage treatment plant in Rio de Janeiro, Brazil
}

\author{
Isabel C. V. Siqueira-Castro; Thiago da S. Paiva \& Inácio D. da Silva-Neto
}

Laboratório de Protistologia, Departamento de Zoologia, Instituto de Biologia, Universidade Federal do Rio de Janeiro. 21941-590 Rio de Janeiro, Rio de Janeiro, Brasil. E-mail: siqueiraicv@gmail.com

\begin{abstract}
In samples of raw sewage collected from a sewage treatment plant in Rio de Janeiro (ETE-Penha), we found populations of two species, Deviata estevesi Paiva \& Silva-Neto, 2005 and Deviata brasiliensis sp. nov. The organisms were studied in vivo under phase contrast microscopy, differential interference contrast (DIC), and after protargol-impregnation. The population of $D$. estevesi exhibited more extensive variation in cirral pattern than previously described. The interphasic organisms of new species $D$. brasiliensis sp. nov. are distinguishable from their congeners based on a series of morphometric features: cirral row R3 usually presents 1-3 cirri behind the right frontal cirrus, on average there are four macronuclear nodules, and, during morphogenesis of cell division, primordium $\mathrm{V}$ of the proter originates from the anterior region of cirral row R5 instead of row R6, as in the type species D. abbrevescens Eigner, 1995. In D. estevesi, the ventral cirral rows replicate by within-row primordia, which develop independently for the proter and for the opisthe, suggesting that it belongs to or is closely related to Parastrongylidium, hence the combination P. estevesi comb. nov. is established.
\end{abstract}

KEY WORDS. Ciliate; Kahliellidae; ontogenesis; Orthoamphisiellidae; Protista.

Deviata Eigner, 1995 (Kahliellidae) is a genus of freshwater and soil stichotrichs that includes four nominal species: $D$. abbrevescens Eigner, 1995, D. bacilliformis (Gelei, 1954) Eigner, 1995, D. estevesi Paiva \& Silva-Neto, 2005, and D. rositae Küppers, Lopretto \& Claps, 2007. This genus is characterized by the presence of more than one long cirral row on the right and the left sides of body, with one of the rows on the right of the adoral zone of membranelles being shortened equatorially, the non-permanence of parental cirri after cell division, and by occurrence of multiple within primordia during divisional morphogenesis (EIGNER 1995).

During a survey on the species of ciliates present in samples of activated sludge from a wastewater treatment plant in Brazil, we found two species of stichotrichs and characterized their morphology during interphase and divisional morphogenesis. One of these species, D. estevesi, is transferred to Parastrongylidium Fleury \& Fryd-Versavel, 1984 (Orthoamphisiellidae) and corresponds to the first record of this species in such habitat. A new species, D. brasiliensis sp. nov., is described based on comparison with congeners.

\section{MATERIAL AND METHODS}

Samples of raw sewage water were collected from the primary settling tanks of Penha Sewage Treatment Plant (ETEPenha), located in the city of Rio de Janeiro, RJ, Brazil, during the period from March 2005 to July 2006. The water character- istics in the samples from which the species were found were: dissolved oxygen concentration $=2.2 \mathrm{mg} / \mathrm{l} ; \mathrm{pH}=7$; temperature $=27.8^{\circ} \mathrm{C}$.

Aliquots of the samples were split into Petri dishes where cultures were made with addition of mineral water and crushed rice grains to favor the growth of bacteria to serve as primary food source for the ciliates (FoIsSNER et al. 2002).

The ciliates were primarily examined in vivo under phase and differential interference (DIC) contrasts to check for the presence of cortical granules, verify the body outline, flexibility, contractile vacuole, details of the cytoplasm and other taxonomic features (Berger 1999, Foissner et al. 2002). Protargolimpregnation (DIECKMANN 1995) and scanning electron microscopy preparations (SILVA-NeTo 1994) were made to examine the ciliature, nuclear apparatus and divisional morphogenesis. Data from tables I and II were obtained from protargol-impregnated specimens observed at 1000x magnification (bright field, oil immersion). All measurements are in micrometers $(\mu \mathrm{m})$. The ventral and lateral cirral rows were numbered according PaIvA $\&$ Silva-Neto (2005) and follow their morphogenetic origin. Statistical procedures were conducted using the software BioEstat 2.0 (Ayres et al. 2004). Schematic drawings of protargolimpregnated specimens were first sketched at 1000x magnification plus a $1.6 \mathrm{x}$ optovar device, with the aid of a camera lucida attached to a Carl Zeiss Axioskop 20 microscope, and then refined with computer image edition software. 
One voucher slide containing specimens of $P$. estevesi from ETE-Penha (IBZ 0007-2) and one slide containing the holotype and several paratypes of D. brasiliensis sp. nov. (IBZ 0007-3) were deposited in the collection of Laboratório de Protistologia, UFRJ.

Both species studied in this paper occurred on 10 of 27 sewage samples. Deviata brasiliensis sp. nov. was also present in fresh samples in natura, co-existing with Paramecium aurelia Ehrenberg, 1838 and testate amoebae. P. estevesi grew concomitantly with Blepharisma sinuosum Sawaya, 1940 and P. aurelia. Observations on cytoplasmic inclusions in protargol slides of $P$. estevesi comb. nov. indicate this organism feeds on flagellates in addition to bacteria. Encystant specimens and conjugant pairs of $P$. estevesi comb. nov. were observed in our cultures (Figs 3 and 6), however, detailed morphological descriptions under those conditions were not carried out in the present study.

\section{TAXONOMY}

\section{Parastrongylidium estevesi (Paiva \& Silva-Neto, 2005) comb. nov.}

Figs 1-20, Tab. I

Redescription: the organisms measure approximately 90 $\mathrm{x} 40 \mu \mathrm{m}$ in vivo, displaying roughly ellipsoid outline, narrowed anteriorly and broader at the posterior end, varying from 2:1 to $6: 1$; with the body slightly dorso-ventrally flattened, flexible and contractile. They exhibit dark coloration under low magnification, conspicuous compact crystals scattered through the cytoplasm alongside with variable sized granulation, but lacked cortical granules. A spheroid contractile vacuole is observed at mid-body, away from the lateral margins, with a dorsal opening pore (Figs 7-9).

The adoral zone of membranelles (AZM) is formed of 2034 membranelles and occupies about $37.5 \%$ of the body length. The undulating membranes are aligned side by side, seldom intersecting each other optically, with the paroral distal end slightly ahead of the endoral (Figs 1, 4, 10, and 12). Frontal and buccal cirri are indistinguishable from ordinary cirri.

The ventral ciliature comprises on average eight cirral rows on the right and five cirral rows on the left of the AZM (Tab. I), with row R3 ending approximately at the equatorial region of the body (Figs 1, 4, 10, and 12). On the dorsal side there are two dikinetid rows, with the right one being posteriorly shortened. A small file of three to five dikinetids is located close to the posterior end of the body, behind the right dorsal kinety (Figs 2, 5, 11, and 13). The nuclear apparatus is composed of usually two macronuclear nodules of roughly spheroid to ellipsoid or ovoid shapes, containing variable sized argentophilic granules. On average, the anterior nodule measures 13.6 × $8.1 \mu \mathrm{m}$ and the posterior one $12.7 \times 8.3 \mu \mathrm{m}$. Two spheroid micronuclei are located near each macronuclear nodule (Figs 1 and 12). In some specimens, the macronuclear nodules are constricted at their equatorial region, becoming dumbbell shaped. A morphometric characterization of the population of P. estevesi comb. nov. from ETE-Penha is shown in table I.

Divisional morphogenesis (Figs 14-20): stomatogenesis of the opisthe is either parakinetal, beginning with proliferation of basal bodies originating adjacent to row R3, or from disaggregating of the posterior-most cirri to the formation of the early oral primordium (Fig. 15). The undulating membranes primordium (primordium I) develops from the right margin of the oral primordium and its distal end produces the cirral row $\mathrm{R} 1$. In the proter, the cirral row R1 is formed likewise from the distal end of the undulating membrane primordium. The cirral primordium II of the opisthe develops from primordium I, whereas in the proter, primordium II develops within the cirral row R2. Rows R3-R6 each develops two independent withinrow primordia for each divider, viz. primordia III-VI (Figs 16 and 18). The left marginal row (L3) of the opisthe develops from within its respective parental row (Fig. 18). Further middleto-late dividers are lacking in ours slides. Based on the configuration of the ciliature in late dividers (Figs 19 and 20) it is possible that all the ventral cirral rows of $P$. estevesi replicate by within-row proliferations of basal bodies, forming independent primordia on each divider. The AZM of the proter remains unchanged during the observed divisional morphogenesis stages, and the undulating membranes disaggregate and form the undulating membrane primordium in early to middle dividers. Later, this primordium splits longitudinally into the new paroral and endoral membranes (Fig. 19).

The dorsal kineties replicates by intrakinetal process. The right kinety forms two distinct separated primordia (one for each divider), whereas within the left kinety, the primordia are only narrowly separated (Figs 17 and 20). Later, the right dorsal row split and formed short posterior fragments, one per divider (Fig. 20). In the divisional morphogenesis of the nuclear apparatus the complete fusion of the macronuclear nodules occurs and further divisional events proceed as in most stichotrichs (Fig. 14). The parental somatic ciliature is likely entirely resorbed by the end of the morphogenetic process.

\section{Deviata brasiliensis sp. nov. Figs 21-27, Tab. II}

Diagnosis: Deviata measuring about $110 \times 45 \mathrm{~mm}$ in vivo $(\mathrm{n}=5)$. With three frontal cirri and one buccal cirrus distinctly isolated from the remaining ventral ciliature; with three to six long cirral rows left and 4-5 right of AZM. Row R4 usually ends at about $4 / 5$ of body length. On average with four macronuclear nodules of variable shape (viz. roughly ellipsoid, ovoid, fusiform or dumbbell-like). Ventral primordium $\mathrm{V}$ of the proter originates from anterior end of row R5.

Type locality: primary settling tanks of the Estação de Tratamento de Esgotos da Penha, ETE-Penha, a sewage treatment plant from Companhia Estadual de Águas e Esgotos (CEDAE/RJ), located in the district of Penha, Rio de Janeiro, state of Rio de Janeiro, Brazil. 

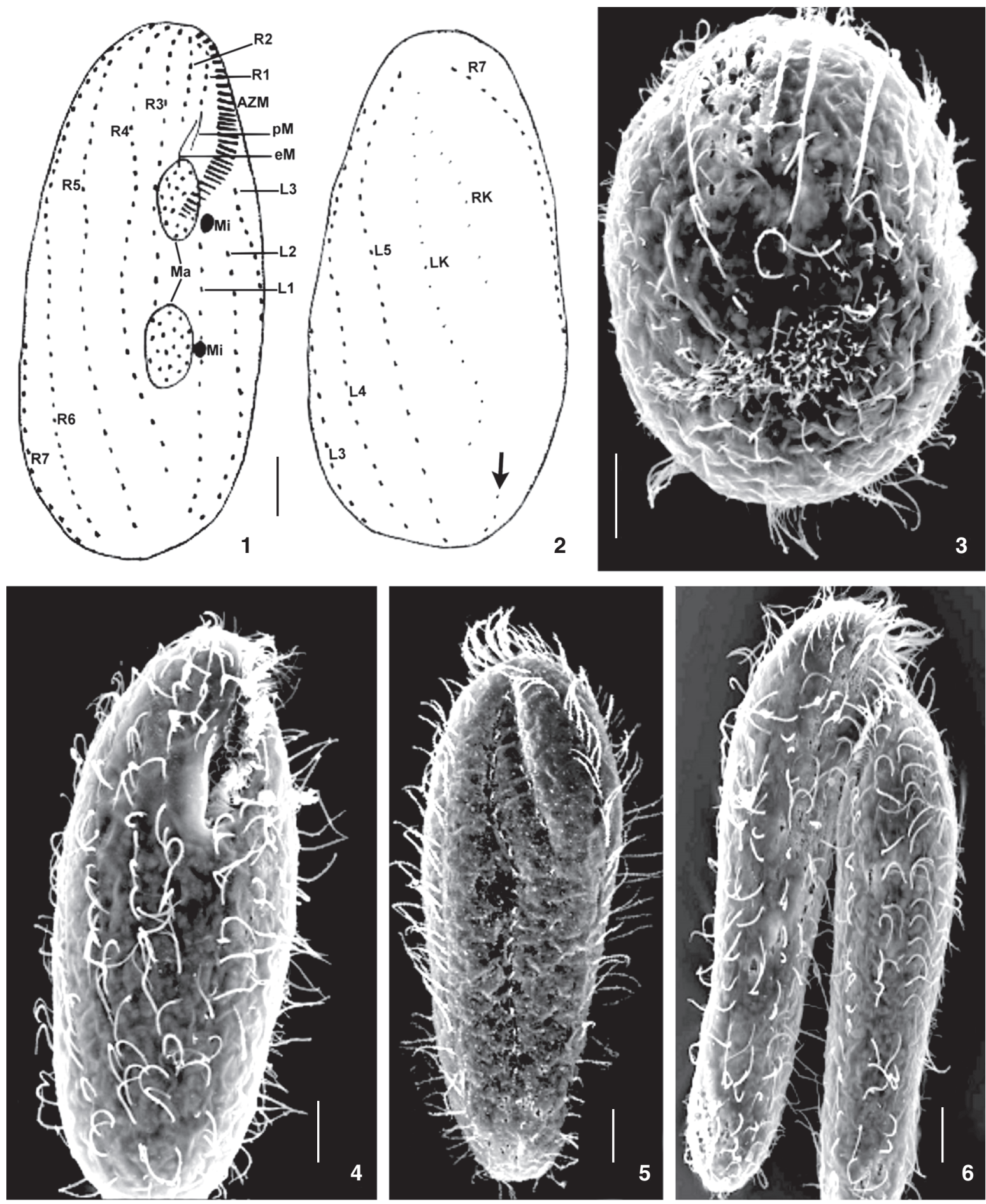

Figures 1-6. Parastrongylidium estevesi comb. nov. (1-2) Schematic drawings of protargol-impregnated specimens: (1) ventral ciliature; (2) dorsal ciliature, arrow 2 points to a short file of dikinetids that splits from the right kinety. (3-6) Scanning electromicrographs: (3) encystant; (4) ventral side; (5) dorsal side; (6) conjugant pair. (AZM) Adoral zone of membranelles, (eM) endoral membrane, (L(n)) cirral row left of AZM, (LK) left dorsal kinety, (Ma) macronuclear nodule, (Mi) micronucleus, $(\mathrm{pM})$ paroral membrane, $(\mathrm{R}(\mathrm{n}))$ cirral row right of AZM. Scale bars: $10 \mu \mathrm{m}$. 


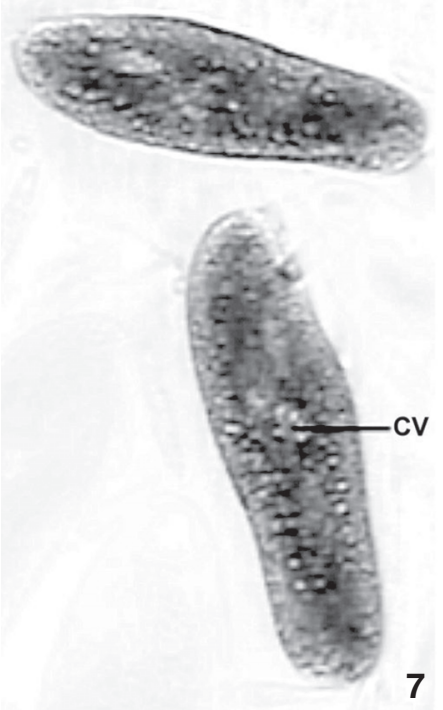

7
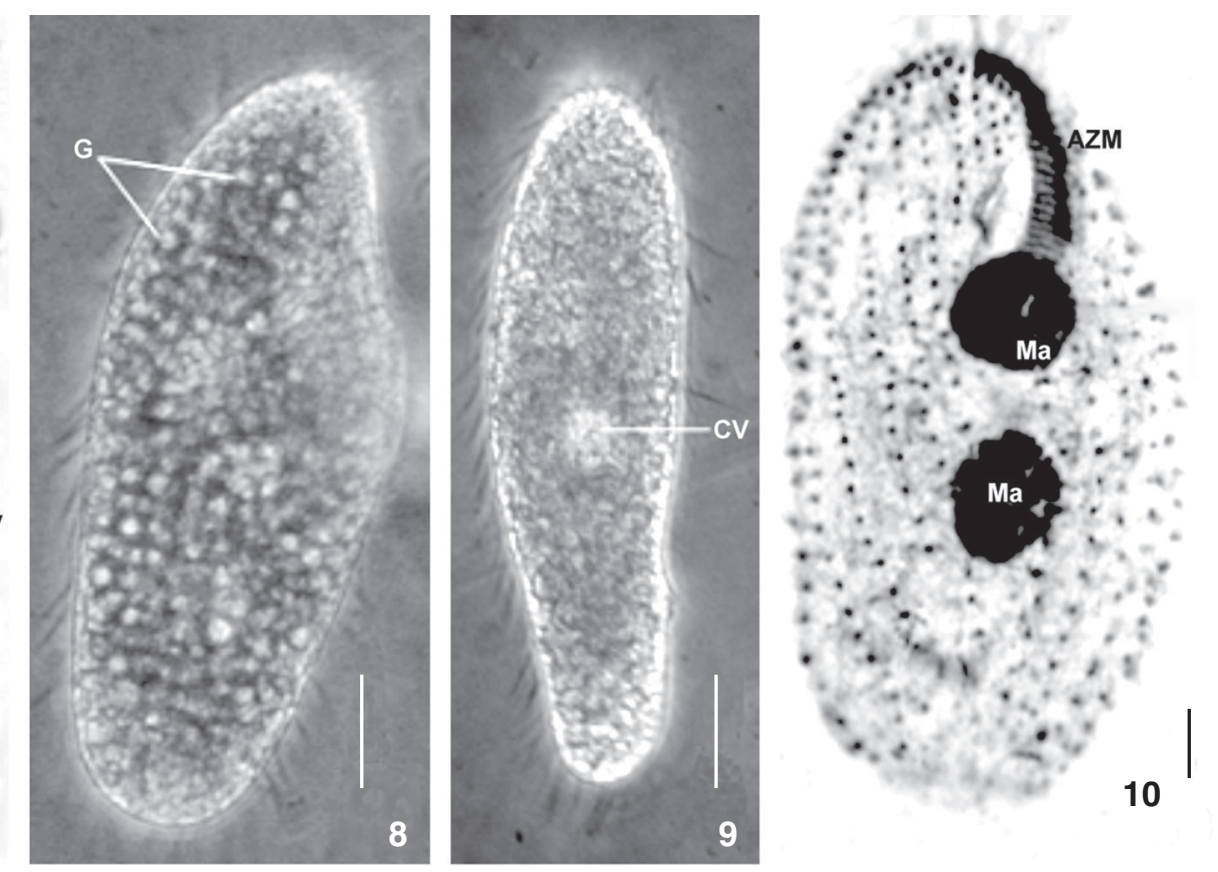
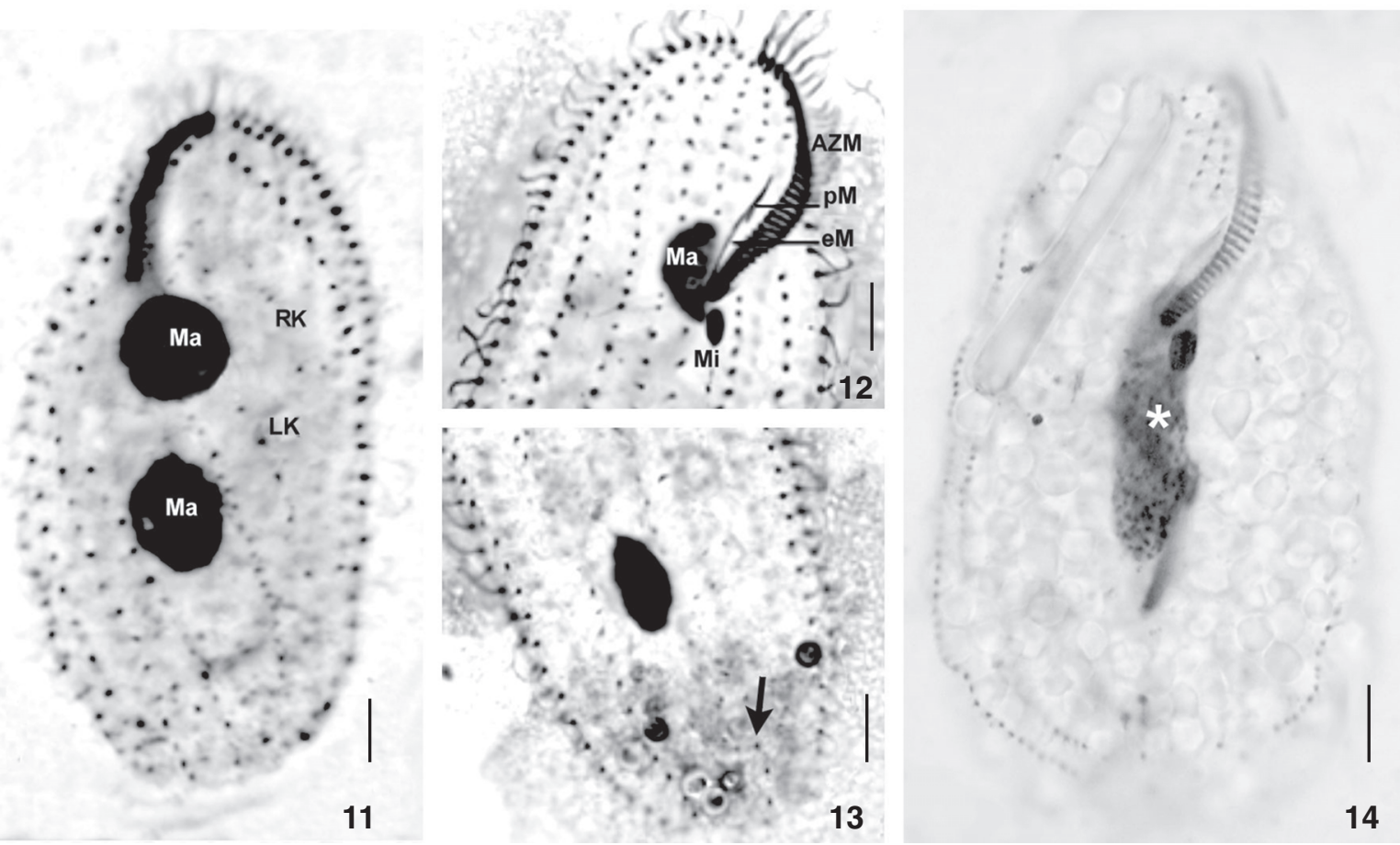

Figures 7-14. Parastrongylidium estevesi comb. nov. (7-9) From life: (7) free-swimming specimens observed under bright field; (8-9) specimens observed under phase-contrast; (10-14) specimens after protargol-impregnation; (10) specimen in ventral view; (11) dorsal side of same specimen; (12) detail of the anterior region of ventral side; (13) detail of the posterior region of dorsal side, arrow marks a short file of dikinetids; (14) late divider from the population of Cabiúnas lagoon (PaIva \& Silva-Neto 2005) showing macronucleus completely fused (asterisk). (AZM) adoral zone of membranelles, (CV) contractile vacuole, (eM) endoral membrane, (G) cytoplasmic granulation (crystals), (LK) left dorsal kinety, (Ma) macronuclear nodule, (Mi) micronucleus, (pM) paroral membrane, (RK) right dorsal kinety. Scale bars: $10 \mu \mathrm{m}$. 
Table I. Morphometric characterization of P. estevesi comb. nov. Upper line: this study; lower line: type population from Cabiúnas Lagoon (Paiva \& Silva-Neto 2005). (Mean) arithmetic mean, (M) median, (SD) standard deviation, (CV) coefficient of variation, (Min) minimum value observed, (Max) maximum value observed, $(n)$ sample size, $(L)$ cirral rows of adoral zone of membranelles (AZM), (R) cirral rows right of AZM.

\begin{tabular}{|c|c|c|c|c|c|c|c|}
\hline Characters & Mean & M & SD & $\mathrm{CV}(\%)$ & Min & Max & $\mathrm{n}$ \\
\hline \multirow[t]{2}{*}{ Body length } & 85.3 & 80.0 & 17.9 & 20.9 & 67.0 & 138.0 & 25 \\
\hline & 86.2 & 84.0 & 7.4 & 8.6 & 75.0 & 100.0 & 25 \\
\hline \multirow[t]{2}{*}{ Body width } & 38.0 & 36.0 & 8.5 & 22.5 & 26.0 & 60.0 & 25 \\
\hline & 42.7 & 44.0 & 8.7 & 20.4 & 27.0 & 60.0 & 25 \\
\hline \multirow[t]{2}{*}{ AZM length } & 32.5 & 33.0 & 2.9 & 8.6 & 25.0 & 38.0 & 24 \\
\hline & 32.5 & 32.5 & 2.8 & 8.8 & 28.0 & 40.0 & 22 \\
\hline \multirow[t]{2}{*}{ Number of adoral membranelles } & 29.4 & 30.0 & 2.9 & 9.9 & 20.0 & 34.0 & 23 \\
\hline & 30.3 & 30.0 & 1.5 & 5.0 & 28.0 & 33.0 & 22 \\
\hline \multirow[t]{2}{*}{ Number of cirral rows left of AZM } & 5.4 & 5.0 & 0.7 & 14.1 & 4.0 & 8.0 & 25 \\
\hline & 4.0 & 4.0 & 0 & 0 & 4.0 & 4.0 & 20 \\
\hline \multirow[t]{2}{*}{ Number of cirri in L1 } & 18.3 & 19.0 & 4.1 & 22.6 & 11.0 & 26.0 & 23 \\
\hline & 17.9 & 19.0 & 1.7 & 9.9 & 14.0 & 20.0 & 15 \\
\hline \multirow[t]{2}{*}{ Number of cirri in L2 } & 19.8 & 21.0 & 4.4 & 22.2 & 13.0 & 28.0 & 23 \\
\hline & 18.2 & 18.0 & 2.2 & 12.3 & 14.0 & 20.0 & 15 \\
\hline \multirow[t]{2}{*}{ Number of cirri in L3 } & 22.1 & 23.0 & 3.8 & 17.1 & 15.0 & 31.0 & 23 \\
\hline & 21.9 & 22.0 & 1.7 & 8.1 & 19.0 & 25.0 & 17 \\
\hline \multirow[t]{2}{*}{ Number of cirri in L4 } & 24.8 & 24.0 & 3.8 & 15.4 & 19.0 & 33.0 & 23 \\
\hline & 24.5 & 24.0 & 3.2 & 13.1 & 20.0 & 32.0 & 17 \\
\hline \multirow[t]{2}{*}{ Number of cirri in $\mathrm{L} 5$} & 27.9 & 27.0 & 4.6 & 16.6 & 20.0 & 37.0 & 23 \\
\hline & - & - & - & - & - & - & - \\
\hline \multirow[t]{2}{*}{ Number of cirri in L6 } & 29.6 & 31.0 & 5.2 & 17.6 & 22.0 & 36.0 & 7 \\
\hline & - & - & - & - & - & - & - \\
\hline \multirow[t]{2}{*}{ Number of cirral rows right of AZM } & 8.0 & 7.0 & 0.8 & 10.5 & 7.0 & 10.0 & 25 \\
\hline & 7.0 & 7.0 & 0 & 0 & 7.0 & 7.0 & 25 \\
\hline \multirow[t]{2}{*}{ Number of cirri in R1 } & 5.8 & 6.0 & 0.9 & 15.7 & 4.0 & 7.0 & 24 \\
\hline & 5.9 & 6.0 & 0.5 & 8.4 & 5.0 & 7.0 & 21 \\
\hline \multirow[t]{2}{*}{ Number of cirri in R2 } & 6.8 & 7.0 & 0.8 & 11.9 & 5.0 & 8.0 & 24 \\
\hline & 7.4 & 7.0 & 0.8 & 11.7 & 6.0 & 9.0 & 21 \\
\hline \multirow[t]{2}{*}{ Number of cirri in R3 } & 15.0 & 16.5 & 3.6 & 24.4 & 9.0 & 20.0 & 24 \\
\hline & 16.0 & 16.0 & 1.9 & 12.0 & 13.0 & 20.0 & 20 \\
\hline \multirow[t]{2}{*}{ Number of cirri in R4 } & 22.2 & 22.5 & 4.7 & 21.1 & 10.0 & 32.0 & 24 \\
\hline & 24.7 & 24.0 & 2.5 & 10.2 & 22.0 & 32.0 & 18 \\
\hline \multirow[t]{2}{*}{ Number of cirri in R5 } & 29.2 & 28.0 & 5.3 & 18.1 & 23.0 & 41.0 & 24 \\
\hline & 27.9 & 28.0 & 2.1 & 7.6 & 24.0 & 32.0 & 17 \\
\hline \multirow[t]{2}{*}{ Number of cirri in R6 } & 33.1 & 34.0 & 5.1 & 15.3 & 18.0 & 42.0 & 24 \\
\hline & 31.4 & 31.5 & 2.2 & 7.1 & 25.0 & 35.0 & 16 \\
\hline \multirow[t]{2}{*}{ Number of cirri in R7 } & 35.9 & 36.0 & 3.7 & 10.4 & 29.0 & 43.0 & 24 \\
\hline & 27.7 & 27.0 & 1.9 & 7.1 & 25.0 & 32.0 & 12 \\
\hline \multirow[t]{2}{*}{ Number of cirri in R8 } & 35.7 & 36.0 & 17.5 & 11.7 & 27.0 & 41.0 & 18 \\
\hline & - & - & - & - & - & - & - \\
\hline \multirow[t]{2}{*}{ Number of cirri in R9 } & 32.8 & 32.0 & 4.0 & 12.2 & 28.0 & 40.0 & 6 \\
\hline & - & - & - & - & - & - & $\begin{array}{c}- \\
\text { Cont }\end{array}$ \\
\hline
\end{tabular}


Table I. Continued.

\begin{tabular}{|c|c|c|c|c|c|c|c|}
\hline Characters & Mean & M & SD & $\mathrm{CV}(\%)$ & Min & Max & $\mathrm{n}$ \\
\hline \multirow[t]{2}{*}{ Number of dorsal kineties } & 2.0 & 2.0 & 0 & 0 & 2.0 & 2.0 & 18 \\
\hline & 2.0 & 2.0 & 0 & 0 & 2.0 & 2.0 & 20 \\
\hline \multirow[t]{2}{*}{ Number of posterior dorsal cilia } & 3.4 & 3.0 & 0.7 & 19.9 & 3.0 & 5.0 & 11 \\
\hline & - & - & - & - & 3.0 & 5.0 & - \\
\hline \multirow[t]{2}{*}{ Number of macronuclear nodules } & 2.1 & 2.0 & 0.5 & 21.1 & 2.0 & 4.0 & 24 \\
\hline & 2.1 & 2.0 & 0.5 & 21.3 & 2.0 & 4.0 & 20 \\
\hline \multirow[t]{2}{*}{ Length of anterior macronuclear nodule } & 13.6 & 13.0 & 3.0 & 22.2 & 7.0 & 21.0 & 24 \\
\hline & 13.3 & 13.0 & 2.1 & 15.8 & 10.0 & 19.0 & 22 \\
\hline \multirow[t]{2}{*}{ Width of anterior macronuclear nodule } & 8.1 & 8.0 & 1.7 & 21.8 & 5.0 & 13.0 & 24 \\
\hline & 8.2 & 7.5 & 2.2 & 27.0 & 5.0 & 12.0 & 22 \\
\hline \multirow[t]{2}{*}{ Length of posterior macronuclear nodule } & 12.7 & 12.5 & 2.7 & 21.1 & 7.0 & 20.0 & 24 \\
\hline & 12.4 & 12.0 & 2.0 & 15.5 & 9.0 & 16.0 & 22 \\
\hline \multirow[t]{2}{*}{ Width of posterior macronuclear nodule } & 8.3 & 8.0 & 2.0 & 24.7 & 5.0 & 13.0 & 24 \\
\hline & 8.1 & 8.5 & 2.2 & 27.5 & 5.0 & 14.0 & 22 \\
\hline \multirow[t]{2}{*}{ Distance between the macronuclear nodules } & 12.1 & 11.0 & 5.2 & 42.8 & 6.0 & 26.0 & 25 \\
\hline & 14.1 & 14.0 & 3.3 & 23.6 & 9.0 & 20.0 & 22 \\
\hline \multirow[t]{2}{*}{ Number of micronuclei } & 2.0 & 2.0 & 0.6 & 27.8 & 1.0 & 4.0 & 16 \\
\hline & 2.2 & 2.0 & 0.4 & 17.3 & 2.0 & 3.0 & 25 \\
\hline \multirow[t]{2}{*}{ Micronuclei diameter } & 2.6 & 3.0 & 0.8 & 30.6 & 2.0 & 5.0 & 15 \\
\hline & 2.8 & 3.0 & 0.3 & 10.7 & 2.0 & 3.0 & 25 \\
\hline
\end{tabular}

Description: specimens of $D$. brasiliensis sp. nov. have an elongate elliptical outline with pointed anterior end, are more or less dorso-ventrally flattened (almost cylindrical in cross-section), flexible and slightly contractile. They exhibit dark color under low magnification, cytoplasm moderately filled with compact crystals, less conspicuous than those from P. estevesi comb. nov. (Fig. 23). Cortical granules are absent. A contractile vacuole is present at equatorial level, adjacent to the left margin of the body (Fig. 23).

The oral apparatus has a short AZM that occupied about $19 \%$ of the body length and is formed by 18-31 membranelles (Figs 21 and 24). The undulating membranes are arranged as described above for $P$. estevesi comb. nov. The organisms exhibit conspicuous cytopharyngeal fibers measuring on average $24 \mu \mathrm{m}$ long (Figs 21 and 26).

The frontal ciliature of $D$. brasiliensis sp. nov. presents three inconspicuously differentiated anterior frontal cirri, roughly aligned horizontally behind the distal membranelles (Figs 21and 24). Behind the right-most frontal cirrus there are one to three extra cirri. A buccal cirrus is located behind the middle frontal cirrus. The ventro-lateral ciliature is formed by 3-6 long cirral rows on the left and 4-5 on the right of the AZM. The first long row from the right (R4) is formed of 10-34 cirri and is shortened posteriorly, ending behind mid-body, at about $4 / 5$ of the body length in most specimens, seldom ending at the equatorial region or at the posterior end of the body.
One specimen, however, had this row distinctly shortened, slight surpassing the AZM level (Fig. 26). In 60\% of the studied specimens, the anterior cirri of $\mathrm{R} 4$ are misaligned in relation to the remaining cirri, sometimes resembling an extra row running parallel to its anterior end (Fig. 21). Rarely, two isolated barren kinetids (dikinetids?) are present in the space between rows R4 and L1 (Fig. 27). On the dorsal side there are two dikinetid rows, of which the right one had the anterior dikinetids densely packed but widely spaced from the equatorial region to the posterior end of the body (Figs 22 and 25).

The nuclear apparatus (Figs 22 and 24) is formed on average by four macronuclear nodules and $2-4$ micronuclei. The shape of the macronuclear nodules is highly variable, ranging from roughly ovoid or ellipsoid to fusiform, being sometimes equatorially constricted, thus becoming dumb-bell shaped. The micronuclei are spheroid. The whole nuclear figure is disposed longitudinally left of the AZM, adjacent to the left margin of the body and the nodules usually are linked by thin isthmuses that stain faintly with protargol. A morphometric characterization of $D$. brasiliensis sp. nov. is shown in table II.

Divisional morphogenesis (Figs 28-39): the stomatogenesis of $D$. brasiliensis sp. nov. is parakinetal alongside to the median region of the shortened ventral row (R4) (Fig. 29). The oral primordium grows posteriad and incorporates posterior-most cirri of row R4 (Figs 30 and 31). It is worth to mention that one specimen exhibit the oral primordium located between rows R4 and 

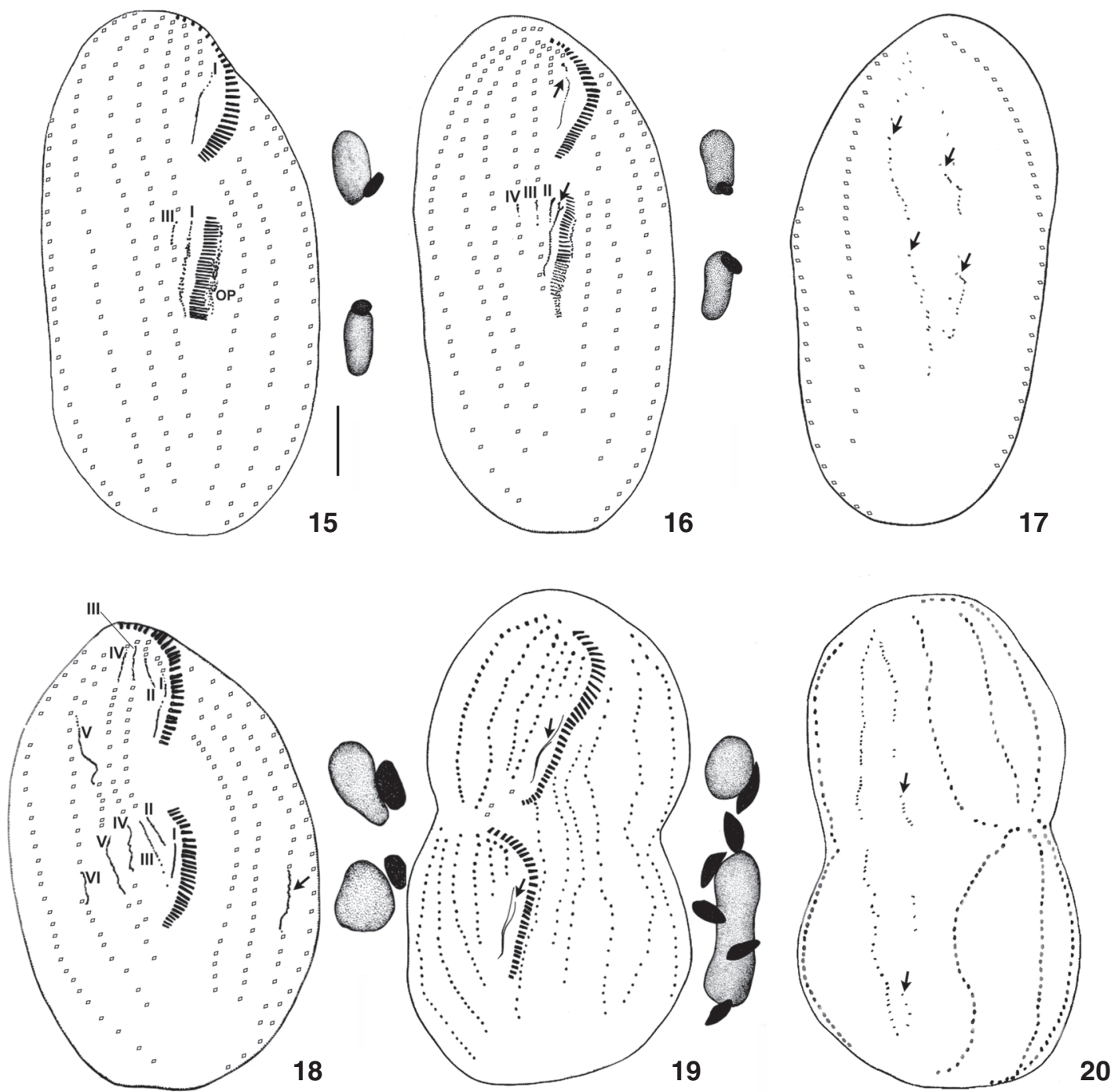

Figures 15-20. Schematic drawings of dividing specimens of $P$. estevesi comb. nov. after protargol-impregnation: (15-16) early morphogenesis of the ventral ciliature, arrows in figure 16 show the early frontal row R1 primordium detaching from the undulating membranes primordium in the opisthe and proter; (17) dorsal side of specimen in 16, showing dorsal kineties primordia (arrows); (18) ventral side of middle divider, arrow points row L3 primordium of the opisthe; (19) ventral side of late divider, arrows show undulating membrane primordium splitting longitudinally into endoral and paroral; (20) dorsal side of same specimen, arrows show fragments of the right kinety primordia, which became the short file of dorsal dikinetids at the posterior end of interphasic specimens. (OP) oral primordium of the opisthe. Ventral cirral primordia are numbered in romans. Scale bar: $10 \mu \mathrm{m}$.

L1. In this specimen the stomatogenesis seems to have occurred de novo, because the parental ciliature seems to remain intact (Fig. 32), but it could also be related to the posterior-most cirrus of R4, since the posterior end of the oral primordium is located near the posterior cirri of this row. In the opisthe, primordia I and II develop from the oral primordium, and primordium III from row R4. The origin of primordia IV and V could not be unambiguously determined. Either both primordia develop from the posterior region of row R5, or primordium IV develops from $\mathrm{R} 5$ and primordium $\mathrm{V}$ originates from row R6, further deviating to R5, as in D. abbrevescens. Primordium VI of the opisthe is a long primary primordium that originates from row R6. In the proter, primordium I originates from the anterior region of the undulating membranes; primordium II develops from the buccal cirrus, and primordium III from the cirri behind the right frontal cirrus. Primordia IV and V originate from the anterior 
region of rows $\mathrm{R} 4$ and $\mathrm{R} 5$ respectively; the long primary primordium VI splits and forms two secondary primordia, one for each divider (Figs 33, 35, 36, and 38). Row R7 produces two withinrow independent primordia, one for each divider. The cirral rows located left of the AZM replicate likewise, by forming two independent within-row primordia, one for each divider (Fig. 36). Noteworthy, one specimen (Figs 28 and 36) exhibited seemingly reorganizing adoral membranelles in the proximal half of the proter's AZM. The paroral and endoral membranes disaggregate and become the undulating membranes primordium only in middle to late dividers. The two dorsal dikinetid rows replicate by intrakinetal process, forming one independent primordium for each divider (Figs 34, 37, and 39). The nuclear apparatus divides as usual, with replication bands developing on each nod- ule and complete fusion of the macronuclear nodules (Fig. 38), thus does not require further explanation. The parental somatic ciliature is very likely entirely resorbed by the end of the morphogenetic process.

Etymology: this species is named "brasiliensis" after the country where it was discovered.

\section{Remarks}

The morphology of P. estevesi comb. nov. from ETE-Penha fits in the description of the type population provided by PAIVA \& Silva-Neto (2005) (Tab. II). Anyhow, we observed a greater variability in the cirral pattern of the presented population, more noticeably concerning the number of cirral rows. We found organisms with eight $(n=18)$, nine $(n=6)$, and ten $(n=$

Table II. Morphometric characterization of Deviata brasiliensis sp. nov. (Mean) arithmetic mean, (M) median, (SD) standard deviation, (CV) coefficient of variation, (Min) minimum value observed, (Max) maximum value observed, (n) sample size, (L) cirral rows left of adoral zone of membranelles (AZM), (R) cirral rows right of AZM.

\begin{tabular}{|c|c|c|c|c|c|c|c|}
\hline Characters & Mean & M & SD & CV(\%) & Min & Max & $\mathrm{n}$ \\
\hline Body length & 107.2 & 104.0 & 24.2 & 22.6 & 62.0 & 160.0 & 45 \\
\hline Cell width & 43.9 & 43.0 & 8.1 & 18.4 & 28.0 & 64.0 & 45 \\
\hline AZM length & 20.8 & 21.0 & 2.5 & 11.9 & 14.0 & 25.0 & 45 \\
\hline Length of the buccal infundibulum & 24.3 & 25.0 & 6.0 & 24.7 & 13.0 & 40.0 & 22 \\
\hline Number of adoral membranelles & 21.9 & 22.0 & 2.2 & 9.9 & 18.0 & 31.0 & 45 \\
\hline Number of frontal cirri & 3.0 & 3.0 & 0 & 0 & 3.0 & 3.0 & 45 \\
\hline Number of buccal cirri & 1.0 & 1.0 & 0 & 0 & 1.0 & 1.0 & 45 \\
\hline Number of cirri behind the right-most frontal cirrus & 1.4 & 1.0 & 0.5 & 38.8 & 1.0 & 3.0 & 44 \\
\hline Number of long cirral rows left of AZM* & 3.9 & 4.0 & 0.8 & 21.5 & 3.0 & 6.0 & 39 \\
\hline Number of cirri in L1 & 29.5 & 29.0 & 5.5 & 18.6 & 17.0 & 41.0 & 40 \\
\hline Number of cirri in L2 & 29.2 & 28.0 & 5.5 & 19.0 & 20.0 & 41.0 & 39 \\
\hline Number of cirri in L3 & 30.5 & 28.0 & 7.1 & 23.3 & 19.0 & 48.0 & 39 \\
\hline Number of cirri in L4 & 26.3 & 27.0 & 4.3 & 16.5 & 13.0 & 34.0 & 25 \\
\hline Number of long cirral rows right of AZM* & 4.2 & 4.0 & 0.4 & 9.2 & 4.0 & 5.0 & 40 \\
\hline Number of cirri in R4 & 20.2 & 21.0 & 6.4 & 31.7 & 10.0 & 34.0 & 40 \\
\hline Number of cirri in R5 & 32.6 & 32.0 & 3.7 & 11.5 & 25.0 & 42.0 & 40 \\
\hline Number of cirri in R6 & 36.9 & 36.0 & 4.9 & 13.3 & 26.0 & 46.0 & 39 \\
\hline Number of cirri in R7 & 36.7 & 35.0 & 6.7 & 18.3 & 26.0 & 52.0 & 38 \\
\hline Number of dorsal kineties & 2.0 & 2.0 & 0.3 & 12.7 & 1.0 & 2.0 & 32 \\
\hline Number of dikinetids in left dorsal kinety & 21.6 & 21.0 & 4.2 & 19.3 & 13.0 & 28.0 & 41 \\
\hline Number of dikinetids in right dorsal kinety & 8.6 & 9.0 & 1.6 & 19.1 & 5.0 & 12.0 & 38 \\
\hline Number of macronuclear nodules & 4.1 & 4.0 & 0.6 & 14.3 & 2.0 & 6.0 & 45 \\
\hline Length of posterior macronuclear nodule ** & 12.9 & 11.0 & 4.8 & 37.1 & 6.0 & 24.0 & 36 \\
\hline Width of posterior macronuclear nodule & 5.0 & 5.0 & 1.4 & 27.1 & 2.0 & 9.0 & 36 \\
\hline Distance between the central macronuclear nodules & 10.5 & 10.0 & 3.6 & 34.2 & 4.0 & 17.0 & 37 \\
\hline Number of micronuclei & 2.5 & 2.0 & 0.7 & 29.9 & 2.0 & 4.0 & 34 \\
\hline Diameter of micronuclei & 2.4 & 2.0 & 0.5 & 23.1 & 2.0 & 4.0 & 34 \\
\hline
\end{tabular}

* Specimens with more than four long rows, several cirri in rows L5, L6 and R8 were masked by preparation artifacts, thus were not accounted. ** The largest values were observed in specimens with two macronuclear nodules. 

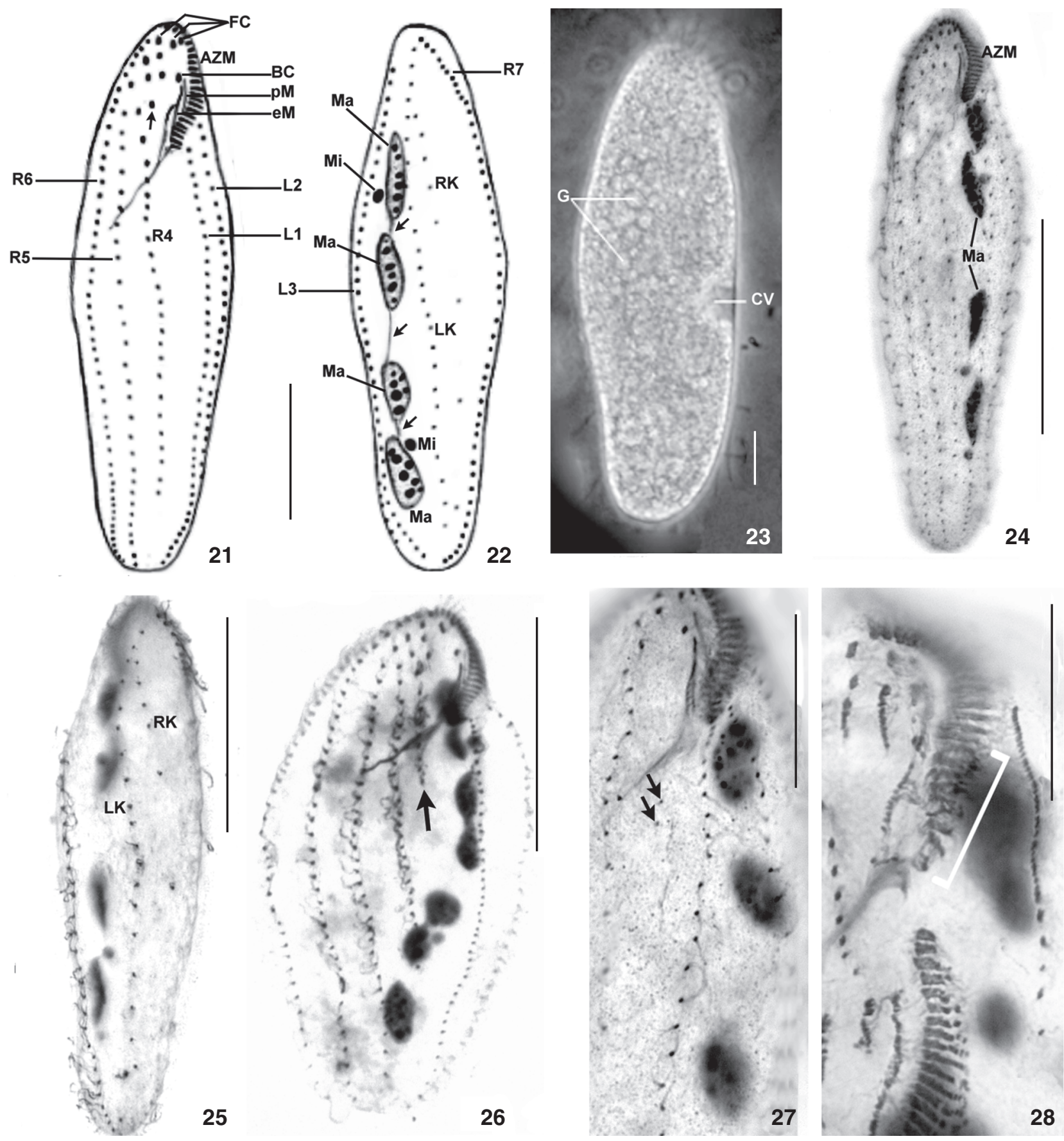

Figures 21-28. Deviata brasiliensis sp. nov. (21-22), schematic drawings of protargol-impregnated specimens: (21) ventral ciliature, arrow points to misaligned cirri in row R4; (22) dorsal ciliature; (23) from life, ventral side of specimen observed under phase contrast; (24-28) specimens after protargol-impregnation: (24) ventral side; (25) dorsal side; (26) ventral side of specimen exhibiting a short row R4 (arrow); (27) specimen with two bare ventral kinetids (arrows); (28) middle divider showing supposed reorganization of the proter adoral membranelles (bracket). (AZM) adoral zone of membranelles, (BC) buccal cirrus, (CV) contractile vacuole, (eM) endoral membrane, (FC) frontal cirri, (L(n)) cirral row left of AZM, (LK) left dorsal kinety, (Ma) macronuclear nodule, (Mi) micronucleus, (R(n)) cirral row right of $A Z M$, (RK) right dorsal kinety. Scale bars: 23: $10 \mu \mathrm{m} ; 21,22,27,28: 20 \mu \mathrm{m} ; 24-26: 50 \mu \mathrm{m}$. 

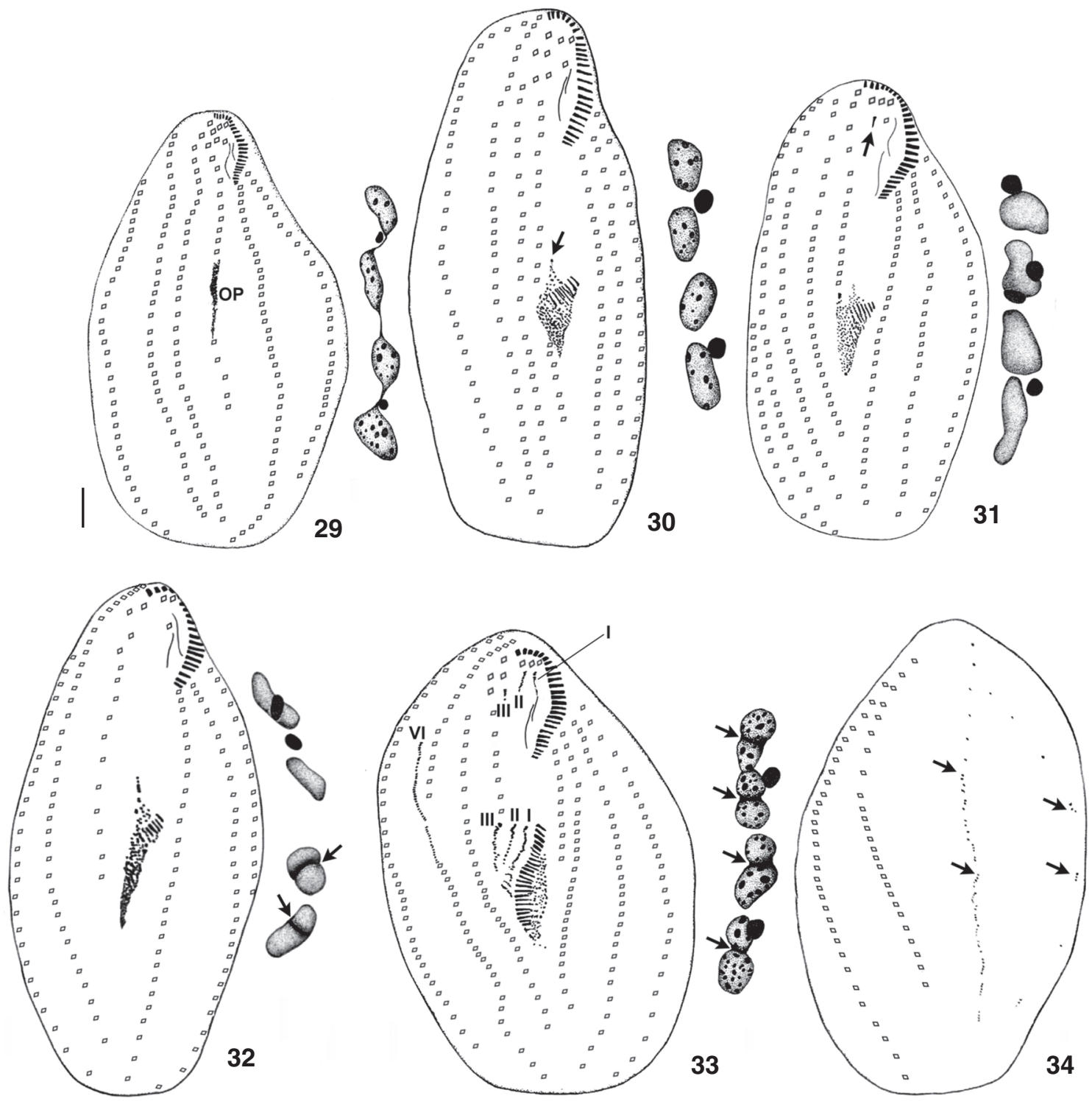

Figures 29-34. Schematic drawings of dividing specimens of $D$. brasiliensis sp. nov. after protargol-impregnation: (29-32) early dividers; (29) early formation of the oral primordium of the opisthe; (30) arrow points a short streak of basal bodies projecting anteriad of the oral primordium, which gave rise to the undulating membranes primordium; (31) arrow points early primordium III of the proter; (32) specimen in which stomatogenesis occurred likely de novo. Arrows mark macronuclear replication bands; (33-34) middle dividers; (33) ventral side of early to middle divider. Arrows show macronuclear replication bands; (34) dorsal side of same specimen. Arrows show dorsal kineties primordia. (OP) oral primordium of the opisthe. Ventral cirral primordia are numbered in romans. Scale bar: $10 \mu \mathrm{m}$.

1) rows on the right of AZM and five $(n=23)$, six $(n=7)$, seven $(\mathrm{n}=1)$, and eight $(\mathrm{n}=1)$ rows left of it. Such range was not observed in the population from Cabiúnas lagoon, which is more stable morphologically (PAIVA \& Silva-NeTo 2005). The variable number of cirral rows is not likely related to nutritional state, since smaller starving individuals and larger ones exhibited similar variability.
The process of divisional morphogenesis in P. estevesi comb. nov. differs from those of $D$. abbrevescens and $D$. brasiliensis sp. nov. in the development manner of primordia IV and V of the opisthe, which are formed each within a different cirral row (vs. primordium IV from R5 and primordium V from R6 and further deviating to R5 in D. abbrevescens, and possible likewise in D. brasiliensis sp. nov.), and primordia VI 

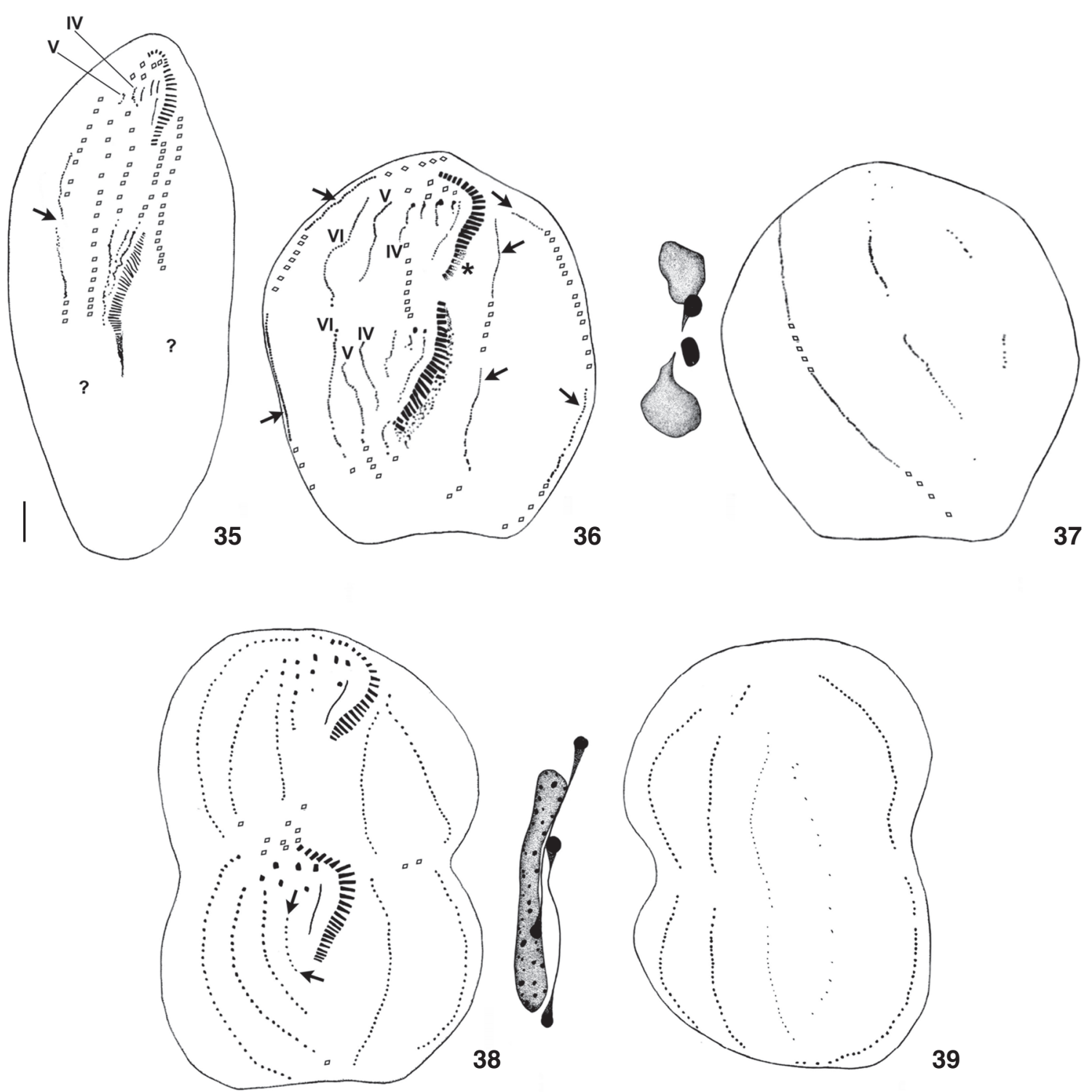

Figures 35-39. Schematic drawings of dividing specimens of $D$. brasiliensis sp. nov. after protargol-impregnation:(35-37) middle dividers; (35) middle divider showing split of primary primordium VI (arrow); (36) ventral side of middle divider, arrows indicate R7 primordia (right side of the body) and primordia of cirral rows left of AZM (left side of the body), asterisk marks supposedly reorganizing membranelles in the proter; (37) dorsal side of same specimen; (38-39) late divider; (38) arrows point to a row which is likely a fragment of primordium IV and may explain the misaligned pattern found in some specimens; (39) dorsal side of same specimen. Ventral cirral primordia are numbered in romans. Scale bar: $10 \mu \mathrm{m}$.

are possibly formed independently on each divider. The short file of dorsal dikinetids located near the posterior end of the body was confirmed to be a fragment of the right dorsal kinety (Paiva \& Silva-Neto 2005), as shown in figure 20.

According to Eigner (1995), the development modes of primordia V and VI by multiple within primordia in Deviata is an important diagnostic feature of this genus, thus the mor- phogenetic processes described in $P$. estevesi comb. nov. indicate it does not belong to Deviata, as originally proposed prior to morphogenetic study. Instead, it is likely related to Parastrongylidium, an orthoamphisiellid in which the right marginal and the ventral ciliatures are morphogenetically indistinguishable and replicate by separated within-row primordia. We thus established Parastrongylidium estevesi comb. nov. 
per D. estevesi. PaIVA \& SILVA-NeTO (2005) document macronuclear replication bands occurring in $P$. estevesi comb. nov., but such structures are almost certainly lacking in Parastrongylidium (Fleury \& Fryd-Versavel 1984, Aescht \& Foissner 1992).

Remarkably, Parastrongylidium estevesi comb. nov. differs from P. martini Fleury \& Fryd-Versavel, 1984, and P. oswaldi Aescht \& Foissner, 1992 by having two dorsal kineties instead of one. In addition, $P$. oswaldi has cortical granules, which are lacking in $P$. martini and $P$. estevesi comb. nov.

Interphasic specimens of Deviata brasiliensis sp. nov. from ETE-Penha differ from those of the type species $D$. abbrevescens by having the cirral row R3 usually shorter, with 1-3 cirri behind the right frontal cirrus (vs. 2-9 in D. abbrevescens) and having on average 4 macronuclear nodules (vs. invariably 2). Concerning morphogenesis, D. brasiliensis sp. nov. differed from D. abbrevescens in the development of primordia IV and $\mathrm{V}$ of the proter, which develop from the anterior region of rows $\mathrm{R} 4$ and R5 respectively (vs. primordium IV originating in row $\mathrm{R} 4$ and further extending into row $\mathrm{R} 5$ and primordium $\mathrm{V}$ originating from the anterior region of row R6 in D. abbrevescens). Anyhow, D. brasiliensis sp. nov. exhibits opisthe morphogenesis that is similar to that of D. abbrevescens (Fig. 36), thus justifying the classification in Deviata. Presumably, the interphasic specimens with misaligned cirri at the anterior region of row R4 had a fragmentation in the corresponding primordium, as suggests the short row in the divider represented in figure 38.

The aforementioned presence of reorganizing membranelles in the proter of a middle divider (Figs 28 and 36) demands further investigation, since the occurrence of this event is unlike in these organisms (EIGNER 1997) and was only observed in one specimen, thus being either an event which happens too quickly during divisional morphogenesis or an anomaly.

Another species which has row R4 ending at the equatorial region and thus is comparable to $D$. brasiliensis sp. nov., is $D$. rositae. This species, however, has less cirral rows on both sides of the body and has more macronuclear nodules (7-14 vs. 2-6 nodules in D. brasiliensis sp. nov.). KüPPERs et al. (2007) reported barren kinetids in ventral surface of $D$. rositae and in a population preliminarily identified as Deviata cf. bacilliformis. These kinetids were associated to the stomatogenesis of the opisthe in the latter species (G.C. Küppers pers. comm.). Similar structures were found in a single specimen of $D$. brasiliensis sp. nov., yet without any apparent association to the formation of the oral primordium.

The morphological variability documented for both $D$. brasiliensis sp. nov. and $P$. estevesi comb. nov. is compatible with the current knowledge of representatives of supposed related genera, as for instance Kahliella multiseta (Dragesco, 1970), Parakahliella macrostoma (Foissner, 1982) and P. haideri Berger \& Foissner, 1989 (Berger et al. 1985, Dragesco 1970, FoIssner 1982). Nevertheless, the variation observed in the stomatogenesis mode of $D$. brasiliensis sp. nov. is probably an anomaly, since this feature is considered to be generally stable in ciliates (CorLISs 1968).
Indeed, the interphasic and morphogenetic patterns of the ciliature in kahliellids (s. l.) have shown to be highly heterogeneous among genera (e.g. FoISSNER et al. 1982, BERGER \& FoISSNER 1988, EIgNer 1995, 1997, Hu \& SoNG 2003). Hence, new studies on morphogenesis of other species of Deviata and related organisms are necessary to better understand this group systematics.

\section{ACKNOWLEDGEMENTS}

Orlando da C. Simões provided technical support. This study was financed by CNPq, FAPERJ and a fellowship granted to Isabel C.V. Siqueira-Castro by CAPES, and is part of her doctoral thesis.

\section{LITERATURE CITED}

Aescht, E. \& W. Foissner. 1992. Biology of a high-rate activated sludge plant of a pharmaceutical company. Archiv für Hydrobiologie 90: 207-251.

Ayres, M.; M. Ayres Jr; C. Murcia; D.L. Ayres \& A.S. Santos. 2004. BioEstat: aplicaciones estadísticas para las ciencias biológicas y médicas. Belém, Sociedade Civil Mamirauá, 274p.

Berger, H. 1999 Monograph of the Oxytrichidae (Ciliophora, Hypotrichia). Monographiae Biologicae 78: XII+1-1080.

Berger, H. \& W. Foissner. 1988. The morphogenesis of Kahliella franzi (Foissner, 1982) nov. comb. and Oxytricha gigantea Horvath, 1933 (Ciliophora, Hypotrichida). Archiv für Protistenkunde 136: 65-77.

Berger, H.; W. FoIsSner \& H. Adam. 1985. Morphological variation and comparative analysis of morphogenesis in Parakahliella macrostoma (Foissner, 1982) nov. gen. and Histriculus muscorum (Kahl, 1932), (Ciliophora, Hypotrichida). Protistologica 21: 295-311.

Corliss, J.O. 1968. The value of ontogenetic data in reconstructing protozoan phylogenies. Transactions of the American Microscopy Society 87: 1-20.

Dieckmann, J. 1995. An improved protargol impregnation for ciliates yielding reproducible results. European Journal of Protistology 31: 372-382.

Dragesco, J. 1970. Ciliés libres du Cameroun. Annales de la Faculté des Sciences, Université Fédérale du Cameroun (Numéro hors-série): 1-141.

EIgNeR, P. 1995. Divisional morphogenesis in Deviata abbrevescens nov. gen., nov. spec., Neogeneia hortualis nov. gen., nov. spec., and Kahliella simplex (Horváth) Corliss and redefinition of the Kahliellidae (Ciliophora, Hypotrichida). European Journal of Protistology 31: 341-366.

EIgner, P. 1997. Evolution of morphogenetic processes in the Orthoamphisiellidae n. fam., Oxytrichidae, and Parakahliellidae n. fam., and their depiction using a computer method (Ciliophora, Hypotrichida). Journal of Eukaryotic Microbiology 44: 553-573.

Fleury, A. \& G. Fryd-Versavel. 1984. Unité et diversité ches les hypotriches (protozoaires ciliés) I. - approche morphogéné- 
tique par l'étude de quelques formes peu différenciés. Protistologica 20: 525-546.

Folssner, W. 1982. Ökologie und Taxonomie der Hypotrichida (Protozoa: Ciliophora) einiger österreichischer Böden. Archiv für Protistenkunde 126: 19-143.

Foissner, W.; H. AdAM \& I. FoIsSNer. 1982. Morphologie und Infraciliatur von Bryometopus pseudochilodon Kahl, 1932, Balantidioides dragescoi nov. spec. und Kahliella marina nov. spec. und Revision des Genus Balantidioides Penard, 1930 (Protozoa, Ciliophora). Protistologica 18: 211-225.

Foissner, W.; S. Agatha \& H. Berger. 2002. Soil Ciliates (Protozoa, Ciliophora) from Namibia (Southwest Africa), with Emphasis on Two Contrasting Environments, the Etosha Region and the Namib Desert. Denisia 5: 1-1459.

Hu, X. \& W. Song. 2003. Redescription of the morphology and divisional morphogenesis of the marine hypotrich Pseudokahliella marina (Foissner et al., 1982) from scallop-culture water of North China. Journal of Natural History 37: 20332043.

Küppers, G.C.; E.C. Lopretto \& M.C. Claps. 2007. Description of Deviata rositae n. sp., a new ciliate species (Ciliophora, Sticotrichia) from Argentina. Journal of Eukaryotic Microbiology 54: 443-447.

Paiva, T.S. \& I.D. SILVA-Neto. 2005. Deviata estevesi sp. nov. (Ciliophora: Spirotrichea), a new ciliate protist from a restinga lagoon in Rio de Janeiro, Brazil. Acta Protozoologica 44: 351-362.

Silva-NeTO, I.D DA. 1994. Observations sur l' ultrastructure du cilié heterotriche Licnophora auerbachi Cohn, 1866, epibionte de l'etoile de mer. Annales des Sciences Naturelles-Zoologie et Biologie Animale 2: 49-62.

Submitted: 27.I.2009; Accepted: 02.XII.2009.

Editorial responsibility: Walter A. Boeger 